\title{
Thermal Cooling with Sprinklers or Microsprinklers Reduces Heat Damage and Improves Fruit Quality in Northern Highbush Blueberry
}

\author{
Fan-Hsuan Yang \\ Department of Horticulture, Oregon State University, 4017 ALS, Corvallis, \\ OR 97331 \\ David R. Bryla and Scott T. Orr \\ U.S. Department of Agriculture, Agricultural Research Service, Horticultural \\ Crop Research Unit, 3420 NW Orchard Avenue, Corvallis, OR 97330
}

Bernadine C. Strik

Department of Horticulture, Oregon State University, 4017 ALS, Corvallis, OR 97331

\section{Yanyun Zhao \\ Department of Food Science \& Technology, Oregon State University, 100 Wiegand Hall, Corvallis, OR 97331}

Additional index words. drip irrigation, fruit firmness, evaporative cooling, soluble solids concentration, titratable acidity, Vaccinium corymbosum

\begin{abstract}
Hot and sunny weather can cause a considerable amount of fruit damage in northern highbush blueberry (Vaccinium corymbosum $\mathbf{L}$.) and result in millions of dollars of crop loss each year. To combat this issue, many growers use over-canopy sprinkler or microsprinkler systems to cool the fruit, but questions remain on the amount of time and frequency these systems should be run and whether they have any effect on fruit quality. Two series of studies were conducted to evaluate the efficacy of using sprinklers or microsprinklers for reducing blueberry fruit temperature and improving fruit quality in western Oregon. With sprinklers, treatments were applied in 2014 and 2015 to 'Elliott' blueberry and included irrigation (night) and cooling (day) with sprinklers, sprinkler irrigation (at night only) with no cooling, and drip irrigation with no cooling. The sprinklers were run for cooling for $\mathbf{1 5}$ minutes every hour whenever air temperature was $\geq 32$ or $35^{\circ} \mathrm{C}$. Berry temperature declined rapidly within the first 15 minutes of cooling and never exceeded ambient air temperature during the cooling cycles. While the percentage of fruit with heat damage was low even without cooling $(<2 \%)$, cooling reduced damage to nearly $0 \%$ in 1 of 2 years and increased berry weight relative to no cooling in both years when it was run at $\geq 32^{\circ} \mathrm{C}$. Cooling also reduced the concentration of soluble solids (sugars) in the berries in 2014 but had no effect on yield, fruit firmness, titratable acidity, harvest date, or the total content of phenolics or anthocyanins in the berries in either year. With microsprinklers, cooling was tested at a commercial farm and at an experimental site. At the farm, 1.3-ha blocks of 'Aurora' blueberry were irrigated by drip and either had no cooling or were cooled using microsprinklers run continuously or pulsed in 1-hour or 20minute cycles during three extreme heat events $\left(\geq 35^{\circ} \mathrm{C}\right)$ in 2015 . Continuous cooling was the most effective treatment for reducing berry temperature, but it resulted in wetter conditions, which might impede fruit harvest afterward and increase the presence of slugs, insect pests, and fungal diseases. Pulsed cooling, especially with short cycles, effectively maintained fruit temperatures near that of ambient air and reduced water use by $50 \%$. At the experimental site, cooling with microsprinklers, which in this case were pulsed in 20min cycles when air temperature was $\geq 32{ }^{\circ} \mathrm{C}$, reduced heat damage in 'Aurora' and 'Elliott' in 2016. Cooling at this site also increased berry weight by an average of $10 \%$ in both cultivars and increased fruit firmness by $32 \%$ during the first of three harvests in 'Aurora'; however, it reduced the concentration of soluble solids in the berries in both cultivars. In general, cooling with microsprinklers used considerably less water than cooling with sprinklers, but it appeared to be equally effective at reducing berry temperature.
\end{abstract}

Blueberry (Vaccinium sp.) is the second most valuable berry crop following strawberry (Fragaria $\times$ ananassa Duch.), and world production volume has increased 24 -fold in the past two decades (Brazelton, 2016). In the United States, the Pacific Northwest is a major blueberry-producing region, accounting for $31 \%$ of the harvested area and $49 \%$ of the total used production in 2018 (U.S. Department of Agriculture National Agricultural Statistics Service, 2019). The majority of the blueberry cultivars in this region are northern highbush ( $V$. corymbosum L.), which ripen during the summer months of June to September. Historically, summer weather conditions in the Pacific Northwest were warm and dry during the day and cool at night; however, weather patterns have become more extreme over the past decade with more sunny days with high temperatures $>35{ }^{\circ} \mathrm{C}$ (Abatzoglou et al., 2014; Houston et al., 2018). This hot and sunny weather has become a persistent threat to production of blueberry and other crops in the region.

High temperature can reduce carbohydrate assimilation, trigger oxidative stress, and diminish fruit quality and shelf life in highbush blueberry (Hancock et al., 1992; Lobos and Hancock, 2015; Moon et al., 1987; $\mathrm{Yu}$ et al., 2016). Previously, we found that necrosis and softening in the berries were the two most common fruit quality disorders that occurred after extreme temperature events in Oregon and Washington (Yang et al., 2019). We also determined that visible signs of heat damage can develop in $<2 \mathrm{~h}$ when berry surface temperature exceeds 42 to $48{ }^{\circ} \mathrm{C}$. Necrosis occurs in both immature and ripe berries and usually starts with distinct browning or reddish spots that eventually collapse within a few days. When necrosis occurs, the berries are unmarketable, particularly for the fresh market. Fruit softening also reduces the marketability of the berries and shortens the shelf life (Ballinger et al., 1973).

Common strategies to prevent heat damage in fruit crops include the use of kaolinbased particle film, shade nets, and evaporative cooling. Kaolin particle film is not an option for blueberry because the surface residue is difficult to remove (Spiers et al., 2003). Shade net successfully reduces fruit surface temperature in apple [Malus ×sylvestris (L.) Mill. var. domestica (Borkh.) Mansf.] (Gindaba and Wand, 2005) and blueberry (Lobos et al., 2013); however, a study in plum (Prunus salicina Lindl.) revealed that it may not always cool the fruit due to slower air movement under the netting (Murray et al., 2005). Shade netting is also costly to install and can delay harvest and impede flower bud initiation, thus reducing yield (Lobos et al., 2013). Evaporative cooling is a process that uses water to remove heat from an object through evaporation. It is relatively easy to do in blueberry fields because growers can use their existing irrigation systems for the process.

A previous study demonstrated that using over-canopy irrigation for evaporative cooling can reduce apple surface temperature and solar injury (Parchomchuk and Meheriuk, 1996). Traditionally, growers in the Pacific Northwest irrigated blueberry using sprinklers (Strik and Yarborough, 2005). When the weather was hot, they usually adapted apple practices and used their sprinkler systems to cool the berries. However, most new blueberry plantings are irrigated using drip 
tubing (Bryla and Strik, 2015), so growers are seeking alternative systems to protect the fruit from summer heat. Adding over-canopy microsprinklers to existing drip-irrigated fields is one option. Using microsprinklers to mitigate high temperatures has been effective in other horticultural crops, including apples and grapes (Vitis sp.) (Aljibury et al., 1975; Caravia et al., 2017; Gindaba and Wand, 2005; Iglesias et al., 2002; Kliewer and Schultz, 1973). By lowering canopy temperature, evaporative cooling can improve carbon assimilation, as well as encourage shoot growth (Aljibury et al., 1975; Gindaba and Wand, 2007; Pelletier et al., 2016).

No prior research has examined whether evaporative cooling can improve fruit quality or alter harvest date in northern highbush blueberry. Therefore, the objective of the present study was to evaluate the efficacy of using over-canopy sprinkler or microsprinkler systems to reduce berry temperature and prevent heat damage and retain fruit quality in two late-season cultivars of northern highbush blueberry, 'Elliott' and 'Aurora'. These two cultivars are harvested in August in western Oregon and are often exposed to hot and dry weather during ripening. 'Aurora' is highly susceptible to heat damage and can have extensive heat scald issues on the surface of the berries, whereas 'Elliott' is less susceptible and the berries mostly soften and shrivel from heat (Yang et al., 2019).

\section{Materials and Methods}

Sprinkler study. A 2-year study was conducted in 2014 and 2015 to evaluate the efficacy of using over-canopy sprinklers for cooling in northern highbush blueberry. The study was set up in an existing planting of 'Elliott' blueberry established in Apr. 2004 at the Oregon State University Lewis-Brown Horticultural Research Farm in Corvallis, OR (lat. $44^{\circ} 33^{\prime} \mathrm{N}$, long. $123^{\circ} 13^{\prime} \mathrm{W}, 68 \mathrm{~m}$ ele-

Received for publication 4 May 2020. Accepted for publication 10 June 2020.

Published online 17 July 2020.

Funds for this research were provided by the Oregon Blueberry Commission and the U.S. Department of Agriculture (CRIS no. 2072-21000048-00D).

We thank Pan American Berry Growers for permission to conduct research at their farm in Salem, OR, Fall Creek Farm and Nursery for providing plants and Wilbur-Ellis Agribusiness for providing fertilizers for the experimental plots, and J. Umble and S. Lukas for reviewing the manuscript. Mention of trademark, proprietary product, or vendor does not constitute a guarantee or warranty of the product by the U.S. Dept. of Agriculture and does not imply its approval to the exclusion of other products or vendors that also may be suitable.

F.-H.Y. is a former Ph.D. student. Current address: Sierra Cascade Nursery, 10230 Santa Fe Drive, Ballico, CA 95303.

D.R.B. is the corresponding author. E-mail: david. bryla@usda.gov.

This is an open access article distributed under the CC BY-NC-ND license (https://creativecommons.org/ licenses/by-nc-nd/4.0/). vation). Soil at the site was a Malabon silty clay loam (fine, mixed, superactive, mesic Pachic Ultic Argixerolls). The plants were spaced $0.8 \times 3.0 \mathrm{~m}$ apart within and between rows, respectively, and grown on 0.4-m high $\times$ $0.9-\mathrm{m}$ wide raised beds. The beds were mulched every 2 to 3 years with a $5-\mathrm{cm}$ deep layer of douglas fir [Pseudotsuga menziesii Mirb. (Franco)] sawdust. Grass alleyways were planted between the beds and mowed as needed. See Bryla et al. (2011) for complete details on establishment and irrigation of the planting. Fertilizers were applied following standard commercial practices for northern highbush blueberry (Bryla and Strik, 2015). Weeds were controlled, as needed, by hand-weeding on the top of beds and by applying glyphosate herbicide at the base of beds. No insecticides or fungicides were applied to the field during the study.

Four treatments were assigned to existing irrigation plots in the field, including two controls with no cooling that were irrigated by drip or sprinklers (at night only) and two cooling treatments that were irrigated (night) and cooled (day) by sprinklers. The cooling treatments were run for 15 min every hour when air temperature was either $\geq 32$ or $35{ }^{\circ} \mathrm{C}$. Any water applied for cooling was subtracted to offset the weekly irrigation requirements. The treatments were arranged in a randomized complete block design and replicated four times. Each block included three rows of plants and was divided into treatment plots with eight plants per row (i.e., 3 rows $\times 8$ plants $/$ row $=24$ plants/plot). All measurements were made on the center six plants in the middle row of each plot, and the remaining plants served as buffers between the treatments.

Sprinkler treatments were cooled and irrigated using $2.8 \mathrm{~L} \cdot \mathrm{min}^{-1}$ pop-up spray heads with preinstalled dual spray quarter-pattern $\left(90^{\circ}\right)$ nozzles (model 1802QDS; Rain Bird Corp., Glendora, CA). The spray heads were mounted on steel posts on the corners of the plots at $\approx 1 \mathrm{~m}$ above the top of the canopy. Each sprinkler covered a radius of $\approx 6 \mathrm{~m}$ when operated at a pressure of 170 to 210 $\mathrm{kPa}$. The drip treatment was irrigated using a line of drip tubing (UniRam 570; Netafim, Fresno, CA) on both sides of the row at a distance of $\approx 0.2 \mathrm{~m}$ from the base of the plants. The tubing had $2 \mathrm{~L} \cdot \mathrm{h}^{-1}$ pressurecompensating emitters integrated every $0.45 \mathrm{~m}$. Irrigation was scheduled based on weather and daily estimates of crop evapotranspiration obtained from a nearby AgriMet weather station (http://usbr.gov/pn/ agrimet) and was run once or twice per week with sprinklers and three to seven times per week with drip, as needed (Bryla, 2011). Cooling was scheduled based on air temperature measured in a drip-irrigated plot and was run automatically using a 16-channel $\mathrm{AC} / \mathrm{DC}$ relay controller and data logger (model SDM-CD16AC and CR-1000, respectively; Campbell Scientific, Logan, UT).

Ripe fruit were picked by hand from each treatment plot on 1 Aug., 15 Aug., and 28 Aug. in 2014 and 5 Aug., 20 Aug., and 2 Sept. in 2015 .
Microsprinkler studies. Two studies were performed to evaluate the use of microsprinklers for cooling blueberries. The first was conducted in 2015 in a 5.4-ha field of ' $\mathrm{Au}$ rora' blueberry located at a commercial farm (Pan-American Berry Growers) near Salem, OR (lat. $45^{\circ} 00^{\prime} \mathrm{N}$, long. $123^{\circ} 56^{\prime} \mathrm{W}, 56 \mathrm{~m}$ elevation). The second study was conducted in 2016 at the Lewis-Brown Farm and included 'Aurora' and 'Elliott' blueberry. In both cases, plants were grown on raised beds and spaced $0.8 \times 3.0 \mathrm{~m}$ apart; grass alleyways were maintained between the beds; and irrigation was applied by drip (two lines per row).

The field in Salem was established in Sept. 2004 and was managed using conventional pesticides and fertilizers. Soil at the site was a Woodburn silt loam (fine-silty, mixed, superactive, mesic Aquultic Argixerolls). The beds were not mulched, and irrigation was scheduled to run day or night by the farm manager. Microsprinklers (Model SuperNet; Netafim, Fresno, CA) were used for cooling and chemigation. The microsprinklers were spaced $3.6 \mathrm{~m}$ apart in every other row (triangular pattern) and installed $\approx 2 \mathrm{~m}$ in height. The system was operated at a pressure of $240 \mathrm{kPa}$ and applied $58 \mathrm{~L} \cdot \mathrm{h}^{-1}$ of water per microsprinkler. Treatments were applied in 2015 and included no cooling, continuous cooling, and pulsed cooling in $1-\mathrm{h}$ or 20-min cycles. The treatments could not be replicated due to the layout of the irrigation system, but each one was applied to 11 rows of plants (1.3 ha). Cooling (continuous and pulsed) was initiated on days when air temperature was $\geq 32{ }^{\circ} \mathrm{C}$ and was stopped at $1900 \mathrm{HR}$. The field was hand-harvested by commercial crews in late July and early August. Nearly $30 \mathrm{t} \cdot \mathrm{ha}^{-1}$ of marketable fruit was produced in the field in 2015 .

The planting at Lewis-Brown was established in Oct. 2008 with 12 rows of 84 plants each (0.23 ha). Mulching and irrigation were done as described in the sprinkler study. See Vargas et al. (2015) for complete details on establishment of the planting. The present study was set up as a $2 \times 2$ factorial experiment, arranged in a randomized complete block design, and compared cooling to no cooling in both cultivars. Each treatment plot consisted of one row of eight plants and was replicated five times. Only the middle six plants in each plot were used for measurements. Hanging fan-jet microsprinklers (DC series; Bowsmith, Exeter, CA) were suspended $\approx 0.6 \mathrm{~m}$ above the canopy between every other plant in the cooling treatments. The microsprinklers had a flow rate of 20 $\mathrm{L} \cdot \mathrm{h}^{-1}$ and were operated at a pressure of 100 $\mathrm{kPa}$. Cooling was controlled automatically, as described earlier, and was pulsed in 20 min cycles when air temperature was $\geq 32{ }^{\circ} \mathrm{C}$. The plants were harvested by hand on 1 Aug., 15 Aug., and 24 Aug. 2016.

Measurements. Berry temperature was measured in each study using $0.13-\mathrm{mm}$, copper-constantan wire thermocouples (Omega Engineering Inc.; Stamford, CT). The thermocouples were inserted beneath 


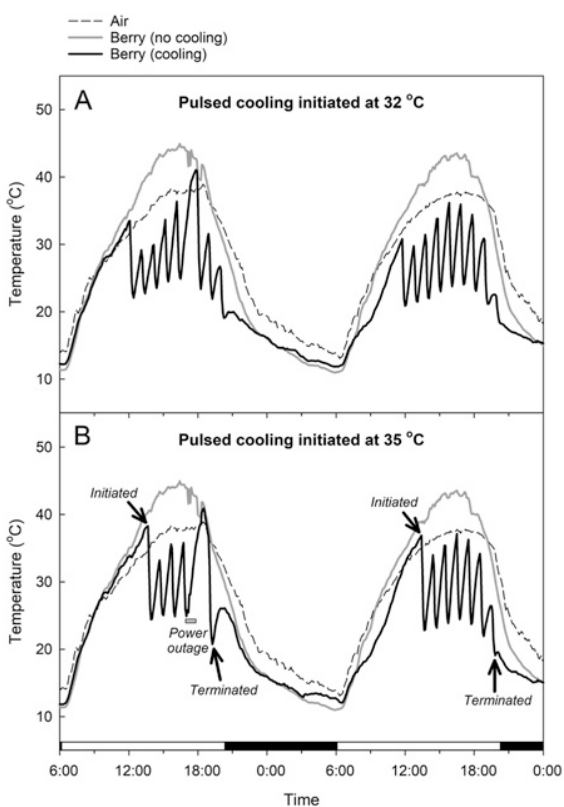

Fig. 1. Ambient air and berry surface temperatures measured in experimental plots of 'Elliott' blueberry in Corvallis, OR. The plots either had no cooling or were cooled using overcanopy sprinklers. The sprinklers were run (pulsed) for 15 min every hour when air temperature was $(\mathbf{A}) \geq 32{ }^{\circ} \mathrm{C}$ or $(\mathbf{B}) \geq 35^{\circ} \mathrm{C}$. The measurements shown here were taken on 30-31 July 2015, during the two hottest days of the year at the site. A cooling cycle was missed on the first date as a result of a power outage. Dark regions on the $\mathrm{x}$-axis indicate night.

the epidermal layer of four berries per cluster. The clusters were randomly selected from the upper west side of the canopy (1.2 to $1.8 \mathrm{~m}$ high) on three or four plants in each treatment plot. Ambient air temperature and relative humidity $(\mathrm{RH})$ were measured in one plot per treatment using a temperature/humidity probe (model HMP60; Vaisala, Woburn, MA). The probes were covered with a sixplate radiation shield (model 41303-5A; RM Young, Traverse City, MI) and mounted $1.8 \mathrm{~m}$ high. Each measurement was recorded every 5 min using data loggers (model CR800 or CR-1000). In Salem, average hourly wind speeds were obtained from a weather station located at the farm (Puresense Environmental Inc., Fresno, CA).

Yield and fruit quality were measured on each harvest date of the sprinkler and the microsprinkler studies at Lewis-Brown. The berries were first weighed from each plot to determine the average yield per plant in each treatment. A random sample of 100 berries was then weighed to calculate the average berry weight and to estimate the total number of berries in each plot. Another 25 berries were randomly sampled to determine firmness using a precalibrated fruit firmness tester (FirmTech2; BioWorks Inc., Wamego, KS). The berries were placed on the turntable of the instrument with calices facing inward and tested through the compression of the load. Reference size and deflection thresholds were set at $18.87 \mathrm{~mm}$

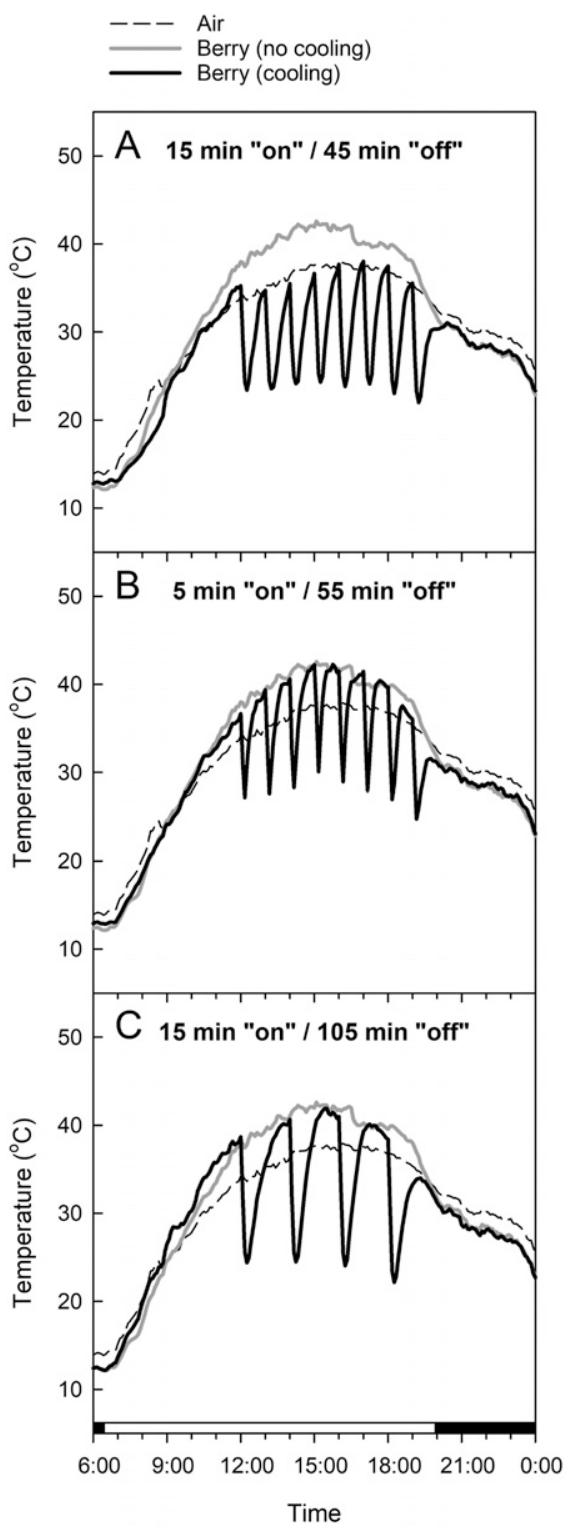

Fig. 2. Ambient air and berry surface temperature measured in experimental plots of 'Elliott' blueberry in Corvallis, OR. The plots either had no cooling or were cooled using overcanopy sprinklers that were run (pulsed) for (A) 15 min every hour, (B) 5 min every hour, or (C) $15 \mathrm{~min}$ every $2 \mathrm{~h}$ when air temperature was $\geq 32{ }^{\circ} \mathrm{C}$. The measurements shown here were taken on 19 Aug. 2016. Dark regions on the xaxis indicate night.

and 0.51 to $1.47 \mathrm{~mm}$, respectively, and the mean of the replicate was recorded as grams of force per millimeter of deflection. Heat damage was assessed visually (Yang et al., 2019) and calculated by dividing the number of damaged berries on the plants (counted before harvest) by the total number of berries from each harvest.

Approximately $150 \mathrm{~g}$ of berries from each plot on each harvest date were frozen in airtight plastic bags in a freezer set at $-16{ }^{\circ} \mathrm{C}$ and later analyzed for soluble solids ( ${ }^{\circ}$ Brix), titratable acidity, and the total content of phenolics and monomeric anthocyanins. The frozen samples were thawed and pureed in a blender and measured for soluble solids using a temperature-compensated re- fractometer (PAL-1; Atago USA Inc., Bellevue, WA). A 10-g sample of the puree was then mixed with $100 \mathrm{~mL}$ of distilled water and titrated with $0.1 \mathrm{~mol} \cdot \mathrm{L}^{-1} \mathrm{NaOH}$ to an endpoint $\mathrm{pH}$ of 8.1 . Titratable acidity was calculated as a percentage of citric acid. To determine phenolics and anthocyanins, samples were homogenized with liquid $\mathrm{N}$ and extracted with acidified $60 \%$ methanol solution (Wang et al., 2016). This last set of procedures was only done in the sprinkler study but included a measurement from every replicated plot in each cooling treatment. Phenolics were measured by colorimetry using Folin-Ciocalteu (FC) reagent and gallic acid (Sigma, St. Louis, MO) as a standard for measuring the changes in absorbance at $765 \mathrm{~nm}$ (Duan et al., 2011). Anthocyanins were measured using a $\mathrm{pH}$ differential method, which is based on the different structure and color absorbance of anthocyanins at 520 and $700 \mathrm{~nm}$ and $\mathrm{pH}$ of 1.0 and 4.5, respectively (Cavender et al., 2014; Wrolstad et al., 2005). All colorimetric measurements were made using the same spectrometer (model UV160U; Shimadzu Co., Kyoto, Japan).

Statistical analysis. Data from the sprinkler study were analyzed by two-way analysis of variance (ANOVA) using R v. 3.4.2 (R Core Team, 2017) and assessed for the effects and interactions of cooling treatment and year or harvest date. Each measurement (heat damage, yield, berry weight, firmness, and other fruit quality characteristics) differed between 2014 and $2015(P \leq 0.05)$ and consequently were analyzed independently by year. However, none of the measurements were significantly different among the harvest dates within a given year. Therefore, each measurement was totaled or averaged and weighted as appropriate and reanalyzed across harvest dates each year. Planned comparisons between the control(s) and cooling treatments were separated at the 5\% level using Fisher's protected least significant difference test.

Data from the microsprinkler study at Lewis-Brown were analyzed by three-way ANOVA with $\mathrm{R}$ and assessed for the effects and interactions of cultivar, cooling treatment, and harvest date. Heat damage, yield, and berry weight did not differ among harvest dates and, therefore, were totaled or averaged and weighted, as appropriate, and reanalyzed for the year. Firmness and other quality characteristics of the berries, on the other hand, were affected by harvest date. Combined effects of cultivar and cooling were separated using Tukey's honestly significant difference test $(P \leq 0.05)$.

\section{Results and Discussion}

\section{Cooling with sprinklers}

Berry temperature. Pulsed cooling with sprinklers was an effective means of reducing berry temperature in the field on warm days (Fig. 1). Berry temperature dropped quickly with each irrigation pulse and remained well below those in the noncooled treatment throughout the cooling period. Interestingly, 
Table 1. Effects of cooling with sprinklers on heat damage in 'Elliott' blueberries during 2014 and 2015 in Corvallis, OR.

\begin{tabular}{lcc}
\hline & & Heat damage (\%) $^{\mathrm{y}}$ \\
\cline { 2 - 3 } Treatment $^{\mathrm{z}}$ & 2014 & 2015 \\
\hline Drip (no cooling) & $1.7 \mathrm{a}^{\mathrm{x}}$ & 1.5 \\
Sprinklers (no cooling) & $0.8 \mathrm{~b}$ & 1.9 \\
Sprinklers (cooling at $\left.\mathrm{T}_{\text {air }} \geq 32^{\circ} \mathrm{C}\right)$ & $0.1 \mathrm{c}$ & 1.0 \\
Sprinklers (cooling at $\left.\mathrm{T}_{\text {air }} \geq 35^{\circ} \mathrm{C}\right)$ & $0.1 \mathrm{c}$ & 1.6 \\
Significance & $* *$ & Ns \\
\hline
\end{tabular}

${ }^{\mathrm{z}}$ Treatments included irrigation by drip and no cooling, irrigation by sprinklers (night only) and no cooling, and irrigation (night) and cooling (day) by sprinklers. During cooling, sprinklers were run for 15 min every hour when air temperature $\left(\mathrm{T}_{\text {air }}\right)$ was $\geq 32$ or $\geq 35^{\circ} \mathrm{C}$.

${ }^{\mathrm{y}}$ Calculated by dividing the number of damaged berries by the total number of berries harvested from a plant.

${ }^{\mathrm{x}}$ Means followed by the same letter within a column are not significantly different $(P>0.05)$, according to Fisher's protected least significant difference test $(P>0.05)$.

NS, **Nonsignificant or significant at $P \leq 0.01$, respectively.

Table 2. Effects of cooling with sprinklers on yield and fruit quality of 'Elliott' blueberry during 2014 and 2015 in Corvallis, OR.

\begin{tabular}{|c|c|c|c|c|c|c|c|c|c|c|c|c|}
\hline \multirow[b]{2}{*}{ Treatment $^{z}$} & \multicolumn{2}{|c|}{ Yield (kg/plant) } & \multicolumn{2}{|c|}{ Berry wt $(\mathrm{g})$} & \multicolumn{2}{|c|}{ Firmness $\left(\mathrm{g} \cdot \mathrm{mm}^{-1}\right)$} & \multicolumn{2}{|c|}{ Soluble solids concn $(\%)$} & \multicolumn{2}{|c|}{ Titratable acidity $(\%)^{y}$} & \multicolumn{2}{|c|}{ Sugar-to-acid ratio ${ }^{x}$} \\
\hline & 2014 & 2015 & 2014 & 2015 & 2014 & 2015 & 2014 & 2015 & 2014 & 2015 & 2014 & 2015 \\
\hline Sprinklers (irrigation only) & 4.4 & 5.9 & $1.25 \mathrm{c}$ & $1.29 \mathrm{ab}$ & 176 & 189 & $13.4 \mathrm{a}$ & 14.2 & 1.27 & 0.93 & 11.3 & 16.0 \\
\hline $\begin{array}{l}\text { Sprinklers (cooling at } \\
\mathrm{T}_{\text {air }} \geq 32^{\circ} \mathrm{C} \text { ) }\end{array}$ & 4.2 & 5.6 & $1.69 \mathrm{a}$ & $1.35 \mathrm{a}$ & 156 & 193 & $11.8 \mathrm{bc}$ & 14.6 & 1.27 & 0.97 & 9.5 & 15.4 \\
\hline $\begin{array}{l}\text { Sprinklers (cooling at } \\
\mathrm{T}_{\text {air }} \geq 35^{\circ} \mathrm{C} \text { ) }\end{array}$ & 5.1 & 5.3 & $1.45 \mathrm{ab}$ & $1.19 \mathrm{~b}$ & 148 & 201 & $11.7 \mathrm{c}$ & 14.5 & 1.20 & 1.03 & 9.9 & 14.3 \\
\hline Significance & NS & NS & ** & * & NS & NS & ** & NS & NS & NS & NS & NS \\
\hline
\end{tabular}

${ }^{\mathrm{z}}$ Treatments included irrigation by drip and no cooling, irrigation by sprinklers (night only) and no cooling, and irrigation (night) and cooling (day) by sprinklers. During cooling, sprinklers were run for 15 min every hour when air temperature $\left(\mathrm{T}_{\text {air }}\right)$ was $\geq 32$ or $\geq 35^{\circ} \mathrm{C}$.

${ }^{\mathrm{y}}$ Expressed as percent citric acid.

${ }^{\mathrm{x}}$ Calculated by dividing soluble solids concentration by titratable acidity.

${ }^{\mathrm{w}}$ Means followed by the same letter within a column are not significantly different, according to Fisher's protected least significant difference test $(P>0.05)$.

Ns, *, ** Nonsignificant or significant at $P \leq 0.05$ or 0.01 , respectively.

berry temperature was also a few degrees lower in cooled than noncooled plots during mornings before cooling (e.g., see the beginning of day 2 in Fig. 1). Iglesias et al. (2002) observed a similar pattern in apple and suggested that this was due to higher humidity and more evaporation and convection in the orchard during the morning on the day after cooling.

When the sprinklers were set to run at air temperatures $\geq 32{ }^{\circ} \mathrm{C}$, cooling occurred on $20 \mathrm{~d}$ in 2014 and $21 \mathrm{~d}$ in 2015. Berry temperatures were only slightly higher when cooling was delayed until $35^{\circ} \mathrm{C}$ (Fig. 1B). At this higher setting, cooling only occurred on $3 \mathrm{~d}$ in 2014 and $10 \mathrm{~d}$ in 2015 and was initiated a few hours later on each of these days. As a result, the total amount of water used for cooling was reduced by $\approx 3.4$ million $\mathrm{L} \cdot \mathrm{ha}^{-1}$ during the first year and 3.0 million $\mathrm{L} \cdot \mathrm{ha}^{-1}$ during the following year. When using sprinklers, this water could be subtracted from the irrigation schedule; however, this would not be the case when a field is irrigated by drip and cooled by microsprinklers (see below).

In 2016, we evaluated two alternative strategies for reducing water usage when cooling with sprinklers (Fig. 2). The first was to shorten the cooling time from $15 \mathrm{~min}$ to 5 min every hour. By doing so, the temperature of the berries did not decline as much during cooling (Fig. 2B). Consequently, the berries were warmer between cycles and approached the same temperature as those in the noncooled treatment. The second strategy was to add an additional hour of "off" time between each cooling cycle. In this case, berry temperature was well above air temperature for 60 to $70 \mathrm{~min}$ between each cooling cycle and was also similar to the measurements in the noncooled treatment (Fig. 2C). Thus, although shorter and less frequent cooling strategies used $33 \%$ and $50 \%$ as much water as cooling for 15 min every hour, respectively, both were less effective at reducing berry temperature. In one instance, berry temperature exceeded $40{ }^{\circ} \mathrm{C}$ for nearly $90 \mathrm{~min}$ (Fig. 2C). We previously found that ' $\mathrm{Au}$ rora' blueberries can be damaged within 1 to $1.5 \mathrm{~h}$ at $42{ }^{\circ} \mathrm{C}$ (Yang et al., 2019). Heat stress might also accumulate in the berries during repeated exposure to high temperature and, over the course of the day, could lead to as much or more damage as continuous exposure to the same temperature. For example, Horowitz and Taylorson (1983) found that multiple short-term heat events were more lethal than a single long-term event in certain weed seeds.

Heat damage, yield, and fruit quality. Cooling with sprinklers reduced heat damage to the berries in 2014 (Table 1). However, this was not the case the following year. In 2015, a 3-d power outage occurred on 17-19 July and prevented the sprinklers from running during a heatwave. At that point, many of the berries on the clusters were still green. Blueberries are more sensitive to heat damage at the green stage of development than during ripening (Yang et al., 2019). Consequently, many berries were damaged during the heatwave, including those in the cooling treatment.

Cooling with sprinklers had no effect on yield, firmness, titratable acidity, or the sugar-to-acid ratio of the berries, but cooling increased berry weight relative to no cooling when it was triggered at air temperatures $\geq 32{ }^{\circ} \mathrm{C}$ in 2014 and 2015 (Table 2).
Triggering sprinklers at temperatures $\geq 35^{\circ} \mathrm{C}$ also increased berry weight relative to using sprinklers for irrigation only in 2014. However, cooling also reduced the concentration of soluble solids (sugars) in the berries in 2014, which potentially could affect their taste and processing quality (Nindo et al., 2005). Reduced soluble solids was likely a dilution effect and a result of larger berries in the treatment (Greer and Weedon, 2014). The effects of cooling on fruit soluble solids are inconsistent in other crops, such as apple (Iglesias et al., 2002; Parchomchuk and Meheriuk, 1996) and grape (Aljibury et al., 1975; Caravia et al., 2017; Greer and Weedon, 2014; Kliewer and Schultz, 1973), and often vary with size and volume of the fruit.

We found no evidence that cooling delayed fruit ripening in terms of the percentage of the total yield picked on each harvest date or that it had any effect on anthocyanin content or total phenolics in the berries (data not shown). However, it is noteworthy that each treatment had higher levels of anthocyanins and phenolics during the second year of the study, which was warmer and drier than the previous year (Yang et al., 2019).

\section{Cooling with microsprinklers}

Berry temperature. The use of microsprinklers was effective at reducing berry temperature at the commercial site in Salem, OR. Within 15 min of continuous operation for cooling, berry temperature dropped to $<30^{\circ} \mathrm{C}$ and remained below air temperature, even after the system was turned off at sunset (Fig. 3A). Pulsed cooling with microsprinklers was also effective and reduced berry 


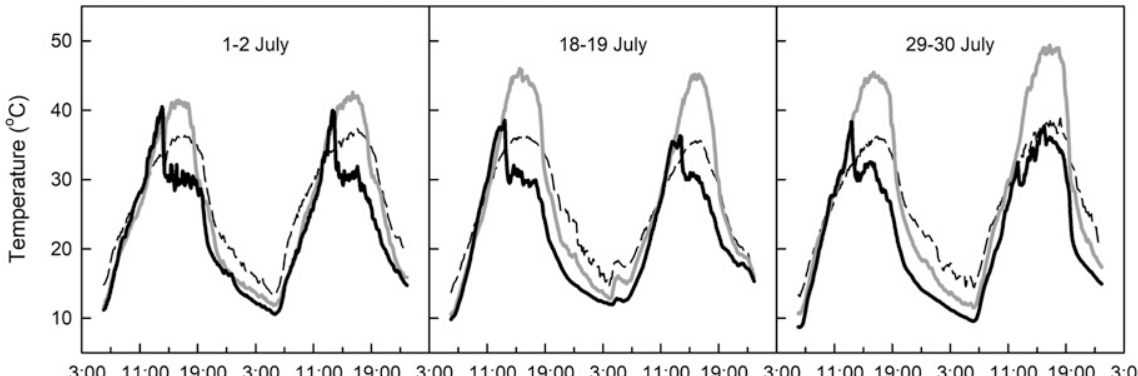

B. Pulsed cooling (1-h cycles)

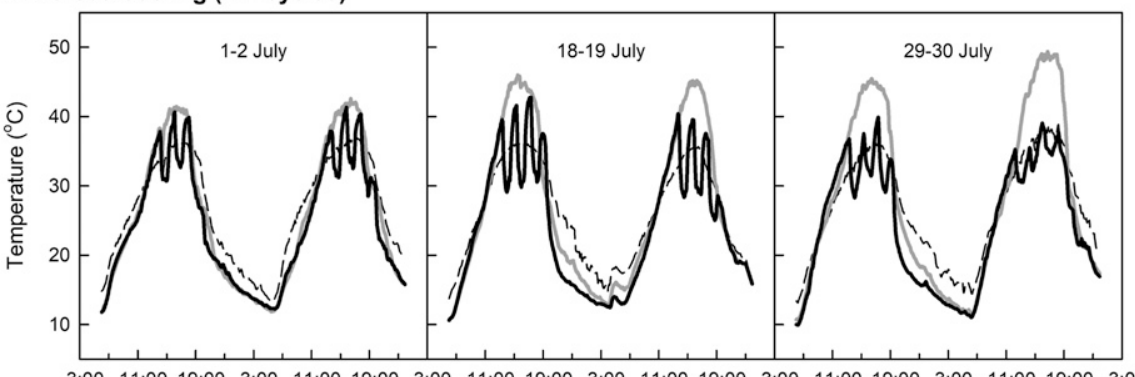

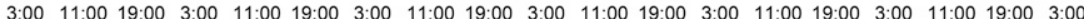

C. Pulsed cooling (20-min cycles)

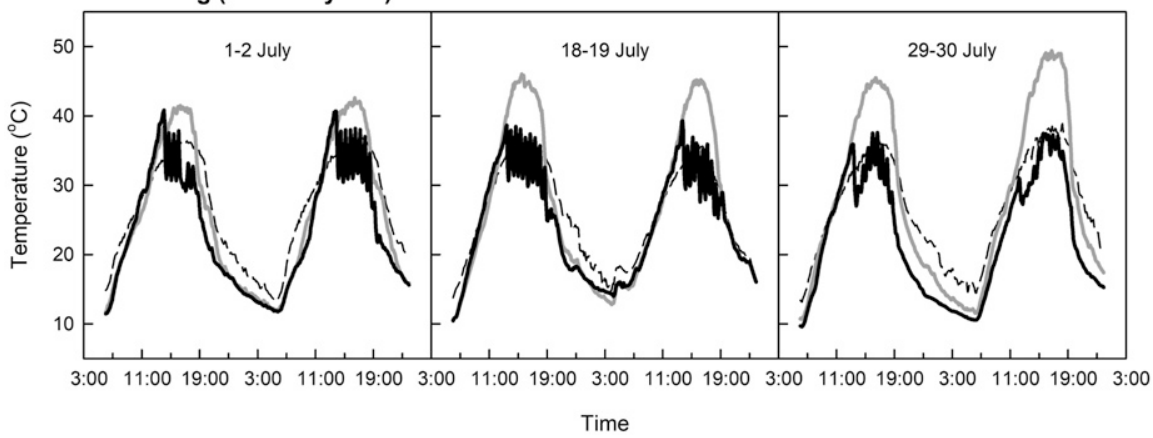

Fig. 3. Ambient air and berry surface temperatures measured in a commercial field of 'Aurora' blueberry in Salem, OR. Large, 1.3-ha blocks of plants at the site either had no cooling or were cooled using overcanopy microsprinklers that were either (A) run continuously or were pulsed in (B) 1-h or (C) 20-min cycles during three extreme heat events $\left(\geq 35^{\circ} \mathrm{C}\right)$ in 2015 . On each date, cooling was initiated between 1200 and $1400 \mathrm{HR}$ and was ended at $\approx 1900 \mathrm{HR}$.

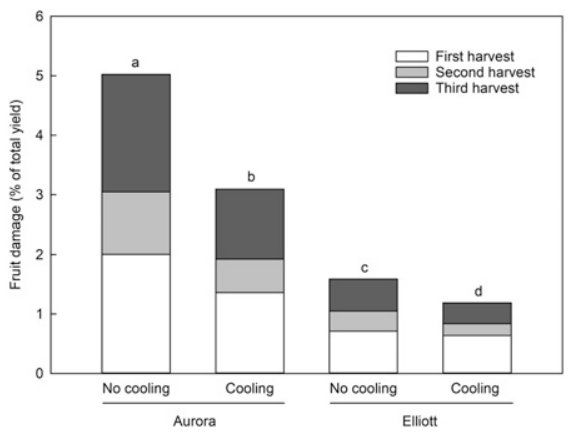

Fig. 4. Percentage of berries with heat damage in experimental plots of 'Aurora' and 'Elliott' blueberry in Corvallis, OR, in 2016. The plots either had no cooling or were cooled using over-canopy microsprinklers that were pulsed in 20 -min cycles when air temperature was $\geq 32^{\circ} \mathrm{C}$

temperature by an average rate of $0.17{ }^{\circ} \mathrm{C} /$ min during each 1 -h cycle (Fig. 3B) and 0.31 ${ }^{\circ} \mathrm{C} /$ min during each 20-min cycle (Fig. 3C). The berries likely cooled faster in the latter latter date, where berry temperature with continuous cooling was similar to air temperature (Fig. 3). Wind reduces the boundary layer on the surface of the berries, allowing more water vapor to evaporate into the air, and creates temperature gradients within the canopy that increase convective cooling (Evans, 2004). Cooling also appeared to be more effective on sunny days than on cloudy days (data not shown). RH is typically higher on cloudy days, reducing the vapor pressure deficit and potential for evaporative cooling (Iglesias et al., 2002; Lakatos and Żyromski, 2012). Therefore, cooling efficiency of blueberry is expected to be high in dry climates, such as eastern Washington, where $\mathrm{RH}$ is usually $<30 \%$ during the summer, and much lower in humid climates, such as Florida, where $\mathrm{RH}$ is often $>80 \%$.

Pulsed cooling (at either 1-h or 20-min cycles) reduced water use by $50 \%$ relative to continuous cooling and resulted in lower $\mathrm{RH}$, not only during cooling but also in the night afterward (data not shown). Excessive moisture created by continuous cooling may be detrimental to berry production. For example, we observed more slugs (Ambigolimax sp., Arion sp., and Deroceras sp.) in plots with continuous cooling than in those with no cooling at the site in Salem (data not shown). The field was also much wetter the day after the system was run continuously than when it was pulsed for cooling, which could affect the harvest schedule, increase the potential for fruit rot (Miles et al., 2013), and exacerbate problems from insect pests such as spotted wing drosophila (Drosophila suzukii Matsumura) (Tochen et al., 2015). In some instances, growers use their microsprinkler cooling systems for applying insecticide to control spotted wing drosophila in blueberry. Excessive cooling afterward could wash off the insecticide, as well as any other chemicals that might be used for controlling insect pests and fungal diseases (Gautam et al., 2016; Hulbert et al., 2012).

Heat damage, yield, and fruit quality. Cooling with microsprinklers significantly reduced the percentage of berries with heat damage at the experimental site $(P<0.05)$. However, damage was only reduced by $38 \%$ in 'Aurora' and by $21 \%$ in 'Elliott' (Fig. 4). The microsprinklers employed in these plots were smaller and provided less coverage than those typically used in commercial operations, including at the site in Salem. Therefore, cooling was probably less effective than normal at preventing heat damage.

Between cultivars, 'Elliott' was less susceptible to heat damage than 'Aurora' $(P<$ $0.001)$. Even without cooling, 'Elliott' had $<2 \%$ total fruit loss in this study, as well as in the previous study with sprinklers (Table 1; Fig. 4). Differences in tolerance to high temperature may occur among cultivars due to variations in cuticular wax or bloom on the berries (Chen et al., 2012; Yang et al., 2019). The wax develops naturally during fruit ripening and acts both as a water barrier and as a reflectant for solar radiation (Jenks and 
Table 3. Effects of cooling with microsprinklers on yield and fruit quality of 'Aurora' and 'Elliott' blueberry during 2016 in Corvallis, OR.

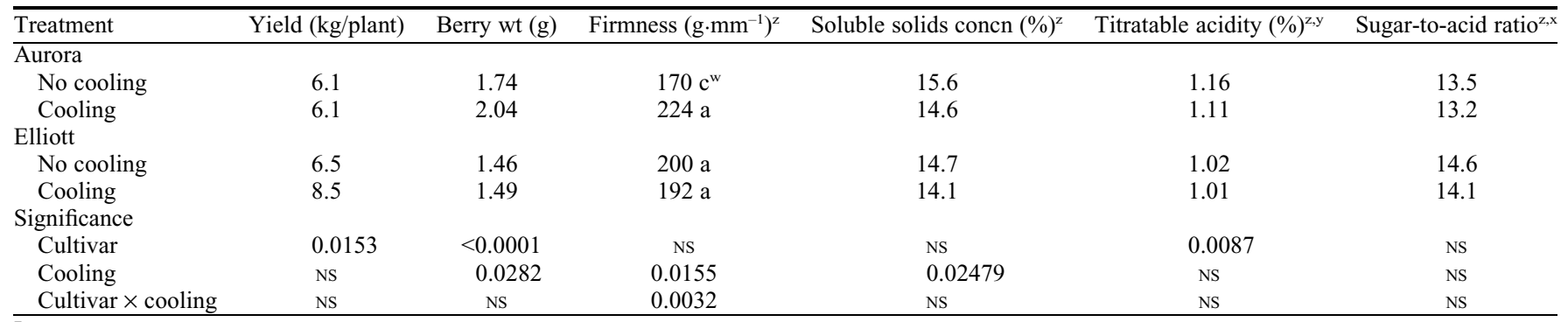

${ }^{\mathrm{z}}$ Data are from the first of three harvest dates in 2016, which accounts for $42 \%$ and $38 \%$ of the total yield with and without cooling, respectively, in 'Aurora', and $65 \%$ and $70 \%$ of the total yield with and without cooling, respectively, in 'Elliott'. None of the measurements were affected by cooling on the latter two harvest dates.

${ }^{\mathrm{y}}$ Expressed as percent citric acid.

${ }^{\mathrm{x}}$ Calculated by dividing soluble solids concentration by titratable acidity.

${ }^{\mathrm{w}}$ Means followed by the same letter within a column are not significantly different $(P>0.05)$, according to Tukey's honestly significant difference test.

NSNonsignificant.

Ashworth, 1999; Yang et al., 2020). Chu et al. (2017) found that the composition of wax varies among blueberry cultivars and suggested that different forms of $\beta$-diketones in the wax may be associated with drought or heat tolerance. Differences in thermotolerance may also be the result of different lipid compositions in the membrane of the fruit cells. High levels of saturated fatty acids in the phospholipid bilayer are generally associated with greater membrane stability under high temperature conditions in different plant organelles (Molina-Bravo and Zamora-Meléndez, 2016), including berries (Wang and Lin, 2006).

Cooling with microsprinklers had no effect on yield, titratable acidity, or the sugarto-acid ratio in either 'Aurora' or 'Elliott', but it increased berry weight in both cultivars (Table 3). Creating a cooler microclimate could increase photosynthesis and minimize the respiratory loss of carbohydrates in the fruit (Aljibury et al., 1975; Caravia et al., 2016; Gindaba and Wand, 2005; Iglesias et al., 2002; Kliewer and Schultz, 1973). In blueberry, photosynthesis declines when air temperature is $>30{ }^{\circ} \mathrm{C}$ (Hancock et al., 1992; Moon et al., 1987); therefore, reducing leaf or berry temperature by evaporative cooling could improve carbon assimilation and increase transport of carbohydrates to the fruit. Microsprinklers also maintained higher berry firmness in 'Aurora' on the first harvest date (Table 3). Preliminary measurements likewise suggested that cooling (continuous or pulsed) increased firmness of the berries (190-200 g. $\mathrm{mm}^{-1}$ per treatment) relative to no cooling $\left(175 \mathrm{~g} \cdot \mathrm{mm}^{-1}\right)$ at the commercial site. Both berry weight and firmness are important traits for fresh market production of northern highbush blueberries. Generally, heavier berries are larger and therefore less time-consuming to hand-pick than smaller berries, while firmer berries ship better and have a longer shelf life than softer berries (Ballinger et al., 1973). However, as in the sprinkler study, cooling also reduced the concentration of soluble solids in the berries (Table 3). Again, this was likely a dilution effect due to larger berries in the treatment.
Fruit firmness typically declines as fruit begin to change color. This softening is associated with cell wall hydrolysis, which commonly involves depolymerization of pectin, cellulose, and hemicellulose (Fischer and Bennett, 1991). In 'Collins' blueberry, pectin hydrolysis enzymes increase as fruit begin to turn pink (Proctor and Miesle, 1991). In 'Duke', fruit soften during development mainly due to depolymerization of hemicellulose (Vicente et al., 2007). The transcription level of these enzymes may be affected by heat stress. It was reported in grape that genes related to cell wall hemicellulose modification were enhanced under heat stress, which may result in the expansion or loosening of cell walls (Lecourieux et al., 2017; Rienth et al., 2014). It is possible that blueberry fruit undergo similar cell wall modifications under high temperatures, which might explain why the berries were firmer after cooling. Further research is needed to investigate changes in the cell wall components of blueberry during heat stress.

Neither berry weight nor firmness were affected by cooling on the subsequent two harvest dates (data not shown). Berries picked later in the season are often shaded within the canopy or cluster and therefore tend to have less heat damage than sunexposed berries, which usually ripen the earliest (Yang et al., 2019). However, the percentage of berries with heat damage was similar between the first and third harvest in 'Aurora' (Fig. 4). In this case, temperature reached $38{ }^{\circ} \mathrm{C}$ just before the third harvest, causing heat damage in many of the remaining berries exposed to sunlight. Most of these berries were only exposed to sunlight after other berries in the cluster were removed.

\section{Conclusions}

Cooling with over-canopy sprinkler or microsprinkler systems was effective for reducing berry temperature during warm weather events in northern highbush blueberry. In addition to protecting the berries from heat damage, cooling also increased berry weight and berry firmness in several cases. Pulsed cooling was generally as effective as continuous cooling but used $50 \%$ less water. Pulsed cooling also resulted in lower relative humidity within the canopy both during and after cooling, which could improve fruit harvest (less moisture on the berries in the morning) and reduce problems from slugs, certain insect pests (e.g., spotted wing drosophila), and fungal diseases relative to continuous cooling.

\section{Literature Cited}

Abatzoglou, J.T., D.E. Rupp, and P.W. Mote. 2014. Seasonal climate variability and change in the Pacific Northwest of the United States. J. Clim. 27:2125-2142.

Aljibury, F.K., R. Brewer, P. Christensen, and A.N. Kasimatis. 1975. Grape response to cooling with sprinklers. Amer. J. Enol. Viticult. 26:214-217.

Ballinger, W.E., L.J. Kushman, and D.D. Hamann. 1973. Factors affecting the firmness of highbush blueberries. J. Amer. Soc. Hort. Sci. 98:583-587.

Brazelton, C. 2016. World blueberry acreage \& production. U.S. Highbush Blueberry Council.

Bryla, D.R. 2011. Crop evapotranspiration and irrigation scheduling in blueberry, p. 167186. In: G. Gerosa (ed.). Evapotranspirationfrom measurements to agricultural and environmental applications. Intech, Rijeka, Croatia.

Bryla, D.R., J.L. Gartung, and B.C. Strik. 2011. Evaluation of irrigation methods for highbush blueberry-I. Growth and water requirements of young plants. HortScience 46:95-101.

Bryla, D.R. and B.C. Strik. 2015. Nutrient requirements, leaf tissue standards, and new options for fertigation of northern highbush blueberry. HortTechnology 25:464-470.

Caravia, L., C. Collins, P.R. Petrie, and S.D. Tyerman. 2016. Application of shade treatments during Shiraz berry ripening to reduce the impact of high temperature. Austral. J. Grape Wine Res. 22:422-437.

Caravia, L., V. Pagay, C. Collins, and S.D. Tyerman. 2017. Application of sprinkler cooling within the bunch zone during ripening of Cabernet Sauvignon berries to reduce the impact of high temperature. Austral. J. Grape Wine Res. 23:48-57.

Cavender, G., M. Liu, D. Hobbs, B. Frei, B. Strik, and Y. Zhao. 2014. Effects of different organic 
weed management strategies on the physicochemical, sensory, and antioxidant properties of machine-harvested blackberry fruits. J. Food Sci. 79:S2107-S2116.

Chen, W., W. Cen, L. Chen, L. Di, Y. Li, and W. Guo. 2012. Differential sensitivity of four highbush blueberry (Vaccinium corymbosum L.) cultivars to heat stress. Pak. J. Bot. 43:853-860.

Chu, W., H. Gao, S. Cao, X. Fang, H. Chen, and S. Xiao. 2017. Composition and morphology of cuticular wax in blueberry (Vaccinium spp.) fruits. Food Chem. 219:436-442.

Duan, J., R. Wu, B.C. Strik, and Y. Zhao. 2011. Effect of edible coatings on the quality of fresh blueberries (Duke and Elliott) under commercial storage conditions. Postharvest Biol. Technol. 59:71-79.

Evans, R.G. 2004. Energy balance of apples under evaporative cooling. Amer. Soc. Ag. Eng. 47:1029-1037.

Fischer, R.L. and A.B. Bennett. 1991. Role of cell wall hydrolases in fruit ripening. Annu. Rev. Plant Physiol. Plant Mol. Biol. 42:675-703.

Gautam, B.K., B.A. Little, M.D. Taylor, J.L. Jacobs, W.E. Lovett, R.M. Holland, and A.A. Sial. 2016. Effect of simulated rainfall on the effectiveness of insecticides against spotted wing drosophila in blueberries. Crop Prot. 81:122-128.

Gindaba, J. and S.J.E. Wand. 2005. Comparative effects of evaporative cooling, kaolin particle film, and shade net on sunburn and fruit quality in apples. HortScience 40:592-596.

Gindaba, J. and S.J.E. Wand. 2007. Climateameliorating measures influence photosynthetic gas exchange of apple leaves. Ann. Appl. Biol. 150:75-80.

Greer, D.H. and M.M. Weedon. 2014. Does the hydrocooling of Vitis vinifera cv. Semillon vines protect the vegetative and reproductive growth processes and vine performance against high summer temperatures? Funct. Plant Biol. 41:620-633.

Hancock, J.F., K. Haghighi, S.L. Krebs, J.A. Flore, and A.D. Draper. 1992. Photosynthetic heat stability in highbush blueberries and the possibility of genetic improvement. HortScience 27:1111-1112.

Horowitz, M. and R.B. Taylorson. 1983. Effect of high temperatures on imbibition, germination, and thermal death of velvetleaf (Abutilon theophrasti) seeds. Can. J. Bot. 61:2269-2276.

Houston, L., S. Capalbo, C. Seavert, M. Dalton, D. Bryla, and R. Sagili. 2018. Specialty fruit production in the Pacific Northwest: Adaptation strategies for a changing climate. Clim. Change 146:159-171.

Hulbert, D., P. Reeb, R. Isaacs, C. Vandervoort, S. Erhardt, and J.C. Wise. 2012. Rainfastness of insecticides used to control Japanese beetle in blueberries. J. Econ. Entomol. 105:1688-1693.

Iglesias, I., J. Salvia, L. Torguet, and C. Cabús. 2002. Orchard cooling with overtree microsprinkler irrigation to improve fruit colour and quality of 'Topred Delicious' apples. Scientia Hort. 93:39-51.
Jenks, M.A. and E.N. Ashworth. 1999. Plant epicuticular waxes: Function, production, and genetics. Hort. Rev. 23:1-68.

Kliewer, W.M. and H.B. Schultz. 1973. Effect of sprinkler cooling of grapevines on fruit growth and composition. Amer. J. Enol. Viticult. 24:17-26.

Lakatos, L. and A. Żyromski. 2012. Possibility for modification of microclimate in orchards by using evaporative cooling irrigation. J. Water Land Dev. 16:29-34.

Lecourieux, F., C. Kappel, P. Pieri, J. Charon, J. Pillet, G. Hilbert, C. Renaud, E. Gomès, S Delrot, and D. Lecourieux. 2017. Dissecting the biochemical and transcriptomic effects of a locally applied heat treatment on developing cabernet sauvignon grape berries. Front. Plant Sci. 8:53.

Lobos, G.A. and J.F. Hancock. 2015. Breeding blueberries for a changing global environment: A review. Front. Plant Sci. 6:782.

Lobos, G.A., J.B. Retamales, J.F. Hancock, J.A. Flore, S. Romero-Bravo, and A. del Pozo. 2013. Productivity and fruit quality of $\mathrm{Vacci}$ nium corymbosum cv. Elliott under photoselective shading nets. Scientia Hort. 153:143-149.

Miles, T.D., J.M. Gillett, A.M. Jarosz, and A.M.C. Schilder. 2013. The effect of environmental factors on infection of blueberry fruit by Colletotrichum acutatum. Plant Pathol. 62:1238-1247.

Molina-Bravo, R. and A. Zamora-Meléndez. 2016. QTLs for genetic improvement under global climate changes, p. 471-513. In: J.M. AlKhayri, S.M. Jain, and D.V. Johnson (eds.). Advances in plant breeding strategies: Agronomic, abiotic and biotic stress traits. Springer International Publishing, Cham, Switzerland.

Moon, J.W., J.A. Flore, and J.F. Hancock. 1987. A comparison of carbon and water vapor gas exchange characteristics between a diploid and highbush blueberry. J. Amer. Soc. Hort. Sci. 112:134-138

Murray, X.J., D.M. Holcroft, N.C. Cook, and S.J.E. Wand. 2005. Postharvest quality of 'Laetitia' and 'Songold' (Prunus salicina Lindell) plums as affected by preharvest shading treatments. Postharvest Biol. Technol. 37:81-92.

Nindo, C.I., J. Tang, J.R. Powers, and P. Singh. 2005. Viscosity of blueberry and raspberry juices for processing applications. J. Food Eng. 69:343-350.

Parchomchuk, P. and M. Meheriuk. 1996. Orchard cooling with pulsed overtree irrigation to prevent solar injury and improve fruit quality of 'Jonagold' apples. HortScience 31:802-804.

Pelletier, V., S. Pepin, J. Gallichand, and J. Caron. 2016. Reducing cranberry heat stress and midday depression with evaporative cooling. Scientia Hort. 198:445-453.

Proctor, A. and T.J. Miesle. 1991. Polygalacturonase and pectinmethylesterase activities in developing highbush blueberries. HortScience 26:579-581.

R Core Team. 2017. R: A language and environment for statistical computing. R Foundation for Statistical Computing, Vienna, Austria. 2 Oct. 2017. <https://www.R-project.org>.

Rienth, M., L. Torregrosa, N. Luchaire, R. Chatbanyong, D. Lecourieux, M.T. Kelly, and C. Romieu. 2014. Day and night heat stress trigger different transcriptomic responses in green and ripening grapevine (Vitis vinifera) fruit. BMC Plant Biol. 14:108.

Spiers, J.D., F.B. Matta, and D.A. Marshall. 2003. Effects of kaolin clay particle film on southern highbush (Vaccinium corymbosum L.) blueberry plants. Small Fruits Rev. 2:2936.

Strik, B.C. and D. Yarborough. 2005. Blueberry production trends in North America, 1992 to 2003, and predictions for growth. HortTechnology 15:391-398.

Tochen, S., J.M. Woltz, D.T. Dalton, J.C. Lee, N.G. Wiman, and V.M. Walton. 2015. Humidity affects populations of Drosophila suzukii (Diptera: Drosophilidae) in blueberry. J. Appl. Entomol. 140:47-57.

U.S. Department of Agriculture National Agricultural Statistics Service. 2019. Noncitrus fruits and nuts 2018 summary. 28 Apr. 2020. <https:// www.nass.usda.gov/Publications/Todays_ Reports/reports/ncit0619.pdf>.

Vargas, O.L., D.R. Bryla, J.E. Weiland, B.C. Strik, and L. Sun. 2015. Irrigation and fertigation with drip and alternative micro irrigation systems in northern highbush blueberry. HortScience 50:897-903.

Vicente, A.R., C. Ortugno, H. Rosli, A.L.T. Powell, L.C. Greve, and J.M. Labavitch. 2007. Temporal sequence of cell wall disassembly events in developing fruits. 2. Analysis of blueberry (Vaccinium Species). J. Agr. Food Chem. 55:4125-4130.

Wang, S.Y. and H.-S. Lin. 2006. Effect of plant growth temperature on membrane lipids in strawberry (Fragaria $\times$ ananassa Duch.). Scientia Hort. 108:35-42.

Wang, W., J. Jung, E. Tomasino, and Y. Zhao. 2016. Optimization of solvent and ultrasoundassisted extraction for different anthocyanin rich fruit and their effects on anthocyanin compositions. Lebensm. Wiss. Technol. 72: 229-238.

Wrolstad, R.E., R.W. Durst, and J. Lee. 2005. Tracking color and pigment changes in anthocyanin products. Trends Food Sci. Technol. 16:423-428.

Yang, F.-H., D.R. Bryla, and B.C. Strik. 2019. Critical temperatures and heating times for fruit damage in northern highbush blueberry. HortScience 54:2231-2239.

Yang, F.-H., L.W. DeVetter, B.C. Strik, and D.R Bryla. 2020. Stomatal functioning and its influence on fruit calcium accumulation in northern highbush blueberry. HortScience 55:96-102.

Yu, K., K. Zhu, M. Ye, Y. Zhao, W. Chen, and W. Guo. 2016. Heat tolerance of highbush blueberry is related to the antioxidative enzymes and oxidative protein-repairing enzymes. Scientia Hort. 198:36-43. 